\title{
TINJAUAN ASPEK KLIMATOLOGI (ENSO DAN IOD) TERHADAP PRODUKSI GARAM INDONESIA
}

\section{THE CLIMATOLOGY ASPECT REVIEW ( ENSO AND IOD ) AGAINST THE PRODUCTION OF SALT IN INDONESIA}

\author{
Rikha Bramawanto dan Rizal Fadlan Abida
}

Pusat Riset Kelautan, Badan Riset dan Sumber Daya Manusia KP - KKP

Komplek Bina Samudera, Jalan Pasir Putih II, Jakarta Utara, 14330

e-mail : bramawant@gmail.com

Diterima tanggal: 14 Desember 2016 ; diterima setelah perbaikan: 7 Maret 2017 ; Disetujui tanggal: 6 April 2017

\begin{abstract}
ABSTRAK
Indonesia yang berada pada wilayah pertemuan Samudera Pasifik dan Samudera Hindia sangat terpengaruh oleh dinamika iklim dan cuaca yang disebabkan oleh adanya ENSO dan IOD. Pengaruh ENSO dan IOD terhadap produksi garam di Indonesia masih belum banyak dikaji. Tulisan ini merupakan kajian literatur yang menyandingkan data ENSO dan IOD dengan curah hujan dan produksi garam. Kejadian El Nino kuat bersamaan dengan IOD positif mengakibatkan musim kemarau panjang sehingga panen garam berlangsung lebih lama dan meningkat kuantitasnya, seperti yang terjadi pada tahun 1972, 1982, 1997, 2006, dan 2015. Sebaliknya kejadian La Nina bersamaan dengan IOD negatif mengakibatkan musim kemarau basah sehingga terjadi gagal panen garam, sebagaimana yang terjadi pada 1998, 2010 dan 2016 . Jika terjadi El Nino sangat kuat bersamaan dengan IOD positif, maka perlu diwaspadai ketika terjadi kecenderungan berubah menjadi La Nina secara drastis apalagi bersamaan dengan fase $I O D$ negatif di tahun berikutnya. Pemahaman terhadap pola siklus ENSO dan $I O D$ dapat menjadi upaya mitigasi dari risiko gagal panen garam serta menjadi dasar bagi pengambil kebijakan untuk menjaga ketersediaan stok garam dalam periode tertentu.
\end{abstract}

Kata kunci: ENSO, IOD, produksi garam, curah hujan, gagal panen.

\section{ABSTRACT}

Indonesia among the Indian Ocean and the Pacific Ocean is highly influenced by the teleconnection of ocean climate and weather dynamics i.e ENSO and IOD. Those existences impact to salt production in Indonesia. This paper is study on how ENSO data and IOD, which focusing on precipitation impacts to salt production. Strong El Nino, which happening at the same time of positive IOD is extending the dry season. These event make salt harvesting in a longer period and it's increasing the salt quality. The case are founded in 1972, 1982, 1997, 2006, and 2015. In contrast scene, when La Nina is happening at the same time of negative IOD, causing an anomaly dry season (wet), then the salt harvesting is fail. These are happened in 1998, 2010 and 2016. If there a very strong El Nino event is happening at the same time of positive IOD positive, we need to setup a preparation for a tendency of strong La Nina event companied by negative IOD for next coming year. Strong La Nina will bring lots of precipitation. The understanding of those phenomenon cycles is very important towards a mitigation efforts to minimizing a risk of failing salt crops. This results can be use for stake holder' references to preserved of salt stock in a certain period.

Keywords: ENSO, IOD, Salt production, Precipitation, Failed Harvest.

\section{PENDAHULUAN}

ENSO (El Niño-Southern Oscillation) merupakan fenomena alam yang melibatkan fluktuasi suhu permukaan laut di wilayah ekuator Samudera Pasifik, yang dikuti dengan perubahan keadaan di atmosfer (Nur'utami \& Hidayat, 2016). ENSO terjadi antara 2 7 tahun sekali. Ketika Perairan Pasifik mengalami peningkatan suhu dan kelembaban pada atmosfer yang berada di atas perairannya, memicu terjadinya pembentukan awan dan meningkatkan curah hujan pada kawasan tersebut. Hal ini membuat Bagian Barat Samudera Pasifik mengalami peningkatan tekanan udara dan terhambatnya pertumbuhan awan. Fenomena tersebut mengakibatkan beberapa wilayah di Indonesia mengalami penurunan curah hujan jauh dari normalnya atau musim kering berkepanjangan yang dikenal dengan El Nino. Sebaliknya, ketika suhu permukaan air laut di kawasan Timur Equator atau di lautan Pasifik mengalami penurunan yang ditandai dengan naiknya 
lapisan termoklin pada bagian tengah dan Timur Samudera Pasifik dan bergesernya zona upwelling pada Samudera Pasifik, mejadikan perairan Indonesia lebih hangat dari keadaan normal. Hal tersebut memicu pertumbuhan awan dan meningkatkan curah hujan di sebagian besar wilayah Indonesia, kondisi ini lazim disebut La Nina. Dari proses terjadinya El Nino akan menyebabkan terjadinya La Nina. Sehingga dapat dikatakan bahwasannya El Nino dan La Nina adalah peristiwa alam yang terjadi secara berturut-turut Biasanya peristiwa seperti ini akan berlangsung menjelang bulan Desember.

Samudera Hindia juga memiliki fenomena yang serupa namun tak sama, fenomena ini sering disebut dengan IOD (Indian Ocean Dipole). IOD adalah fenomena lautan atmosfer di daerah ekuator Samudera Hindia yang mempengaruhi iklim di Indonesia dan negaranegara lain yang berada di sekitar cekungan (basin) Samudera Hindia (Saji et al., 1999). Berbeda dengan ENSO yang memiliki nama berbeda, IOD hanya memiliki kondisi Positif (+) dan Negatif (-) seperti yang tertampil pada Gambar 1. IOD $(+)$ ditandai dengan menghangatnya perairan di Samudera Hindia bagian Barat (Benua Afrika) lebih hangat dibandingkan dengan Samudera Hindia bagian Timur (Indonesia). Sedangkan IOD (-) adalah kebalikan dari IOD (+) yaitu dengan menghangatnya bagian Timur Samudera Hindia dan lebih rendahnya suhu di bagian Barat Samudera Hindia. Fenomena tersebut memainkan peranan penting terhadap cuaca di Indonesia selama satu tahun. Menurut (Endo \& Tozuka, 2016) IOD dibagi menjadi IOD canonical yang berkaitan dengan anomali negatif/positif SST di bagian tengah sampai
Barat Samudera Hindia tropis dan IOD modoki yang berkaitan dengan anomali negatif di bagian Barat dan Timur serta anomali positif di bagian tengah Samudera Hindia tropis

Selain mempengaruhi kondisi curah hujan, kejadian El-Nino berpengaruh pula pada bergesernya musim, hal ini mengakibatkan terjadinya perubahan pola iklim tahunan seperti terlambatnya awal musim hujan maupun musim kemarau. IOD turut mengambil peran penting pula dalam keadaan musim di Indonesia jika dibarengi dengan fenomena ENSO, baik El-Nino dan La-Nina. Berdasarkan sejumlah penelitian terhadap ENSO dan IOD serta pengaruh anomali yang ditimbulkannya terhadap kondisi klimat di Indonesia, Mulyana (2000) menemukan korelasi yang tinggi antara curah hujan di Jawa dengan anomali suhu permukaan laut di Samudera Pasifik dan Samudera Hindia yang lebih dipengaruhi oleh ENSO dan IOD. Menurut Ina et al. (2008) distribusi frekuensi curah hujan lima harian (pentad) di wilayah Indonesia lebih dipengaruhi oleh fenomena ENSO dan IOD. Analisis pendugaan datangnya musim kering di Indonesia sebagai dampak fenomena hasil silang ENSO dan IOD (Hermawan, 2013). Menurut Fadholi (2013) meneliti lebih spesifik mengenai dampak ENSO dan IOD terhadap curah hujan di Pangkalpinang. Sedangkan Lee (2015) melihat lebih jauh korelasi antara pola curah hujan umum, ENSO, IOD dan suhu permukaan laut di Samudera Pasifik dan Hindia.

Beberapa hasil montoring dan riset menampilkan kompilasi dari kombinasi kejadian ENSO dan IOD (Tabel 1). Informasi tersebut dibuat untuk melihat efek

\section{Indeks Osilasi Selatan dan Dipole Samudera Hindia}

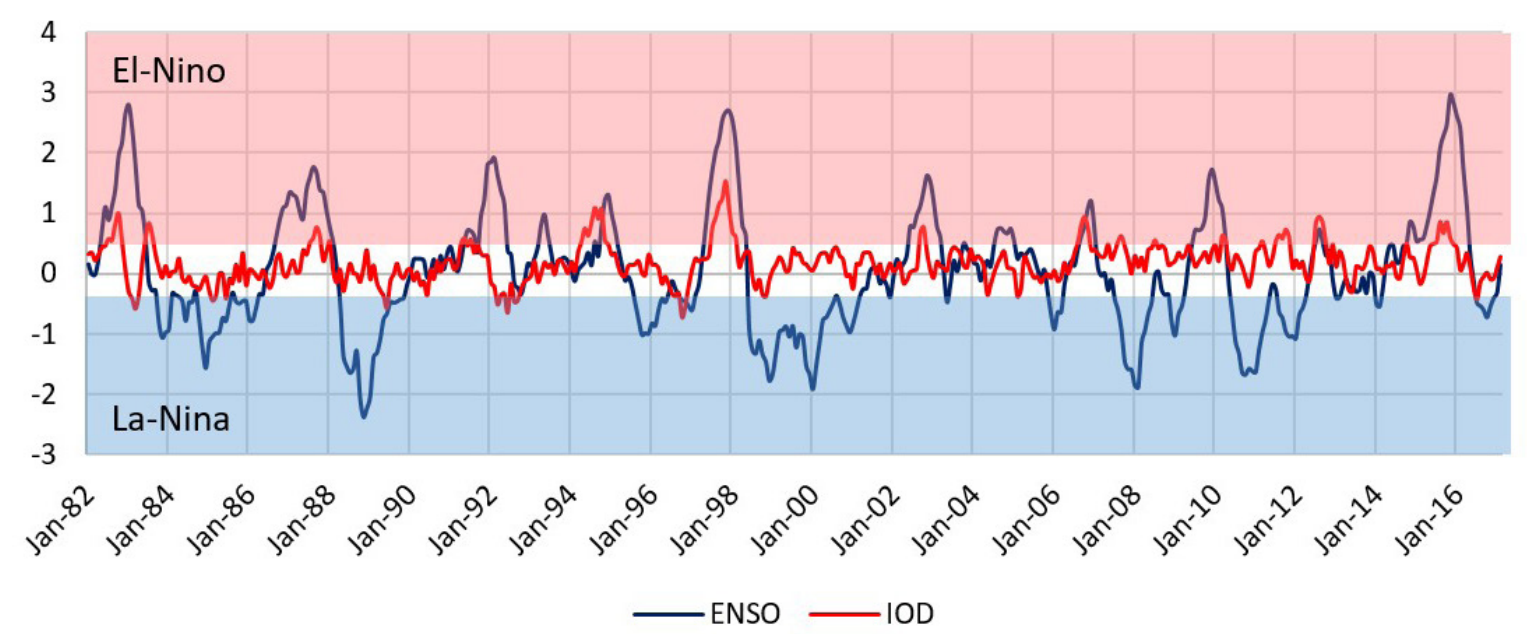

Gambar 1. Grafik Indek Osilasi Selatan dan Dipole Samudera Hindia

Figure 1. Graph of Southern Oscillation Index and Indian Ocean Dipole 
Tabel 1. Tahun kejadian ENSO dan IOD

Table 1. Years of ENSO and IOD incidents

\begin{tabular}{llll}
\hline & IOD fase negatif & Netral & IOD fase positif \\
\hline El Nino Sangat Kuat & & & 198219972015 \\
El Nino Kuat & & 1965 & 1972 \\
El Nino Sedang & & 1966198720022009 & 19631991 \\
El Nino Lemah & & 2004 & 196919761979 \\
& & 1962196619781980 & 19612012 \\
Normal & 1960198119891992 & 1985199019932001 & \\
& 199620132014 & 200320052008 & \\
La Nina Lemah & 196419742016 & 1970197119841995 & 196719721983 \\
& & 20002011 & \\
La Nina Sedang & 19982010 & 19992007 & \\
La Nina Kuat & 197319751988 & & \\
\hline
\end{tabular}

Sumber: www.ggweather.com; www.bom.gov.au; (Meyers, McIntosh, Pigot, \& Pook, 2007)

yang ditimbulkan dari adanya kombinasi dua kejadian tersebut terhadap kondisi cuaca di Indonesia.

Anomali kondisi iklim sangat mempengaruhi produksi komoditas pangan (Apriyana \& Kailaku, 2015; Ruminta, 2009). Pada kejadian El Nino, ketersediaan air berkurang sehingga menurunkan produksi dan produktivitas tanaman. Sebaliknya pada kejadian $\mathrm{La}$ Nina, ketersediaan air berlebihan dan menyebabkan banjir. Dalam kondisi yang sangat ekstrim keduanya berpotensi menyebabkan gagal panen (Utami et al., 2011). Beberapa literatur juga menyebutkan bahwa siklus Indian Ocean Dipole juga mempengaruhi perubahan pola distribusi, intensitas dan periode musim hujan (Lan, 2012).

Pendekatan penggunaan informasi klimatologis yang sedikit berbeda terjadi pada produksi garam. Secara umum masyarakat memahami bahwa kejadian El Nino cenderung menguntungkan petambak garam, karena musim kemarau berlangsung lebih lama sehingga memperpanjang masa produksi garam dan meningkatkan kuantitas produksi. Sedangkan beberapa kejadian La Nina sering diasosiasikan dengan kondisi kemarau basah yang mengganggu proses produksi garam, sebagaimana yang terjadi pada tahun 2010, 2013 dan 2015. Namun informasi yang menyatakan bahwa kejadian El Nino - La Nina, dan kombinasinya dengan fase Indian Ocean Dipole mempengaruhi produksi garam di Indonesia masih sulit ditemukan. Kalaupun ada, sifat kajiannya hanya menggambarkan dampak dari adanya fenomena anomali iklim terhadap produksi garam di beberapa wilayah Indonesia (Kurniawan, T. \& Azizi, 2012; Wahyono et al., 2012).
Kehidupan manusia tidak dapat dipisahkan dari garam. Garam yang memiliki nama kimia Natrium Klorida merupakan bagian penting dari cairan ekstraseluler membantu menjaga keseimbangan asam dan basa sekaligus membantu mempertahankan tekanan osmosis dalam tubuh manusia. Di bagian lain, pertumbuhan industri yang pesat menempatkan garam sebagai salah satu bahan baku anorganik terbanyak yang diperlukan untuk menghasilkan klorin dan soda kaustik. Bahan tersebut dipergunakan dalam industri kertas, PVC, plastik dan lain-lain. Garam juga berfungsi sebagai pengemulsi seperti pada industri karet sintetis, mordant pada proses pewarnaan tekstil, bahan pengawet makanan, dan berbagai fungsi lainnya.

Data produksi garam (gambar 2) yang dikompilasi oleh Aligori, A (2013) dari Kementerian Perindustrian, merupakan data produksi garam pada periode tahun 2001 hingga tahun 2008. Seangkan data produksi tahun 2009 hingga 2015 merupakan informasi dari Kementerian Kelautan dan Perikanan (Anonim, 2015). Sedangkan data produksi garam tahun 2016 diperoleh dari laman berita Kementerian Kelautan dan Perikanan. Rata-rata produksi garam selama tahun 2001 hingga tahun 2016 sebesar 1.303.507,06 ton, hal tersebut sangat jauh jika dibandingkan dengan kebutuhan garam nasional yang mencapai 3,6 juta ton per tahun (KKP, 2015).

Melihat pentingnya keberadaan garam serta perubahan iklim dan cuaca sebagai faktor pembatas produksinya, maka perlu dilakukan suatu kajian untuk mendapatkan komparasi antara nilai SOI, IOD terhadap produksi garam. Informasi ini dapat digunakan oleh petambak untuk mengurangi dampak kerugian akibat pengeluaran 


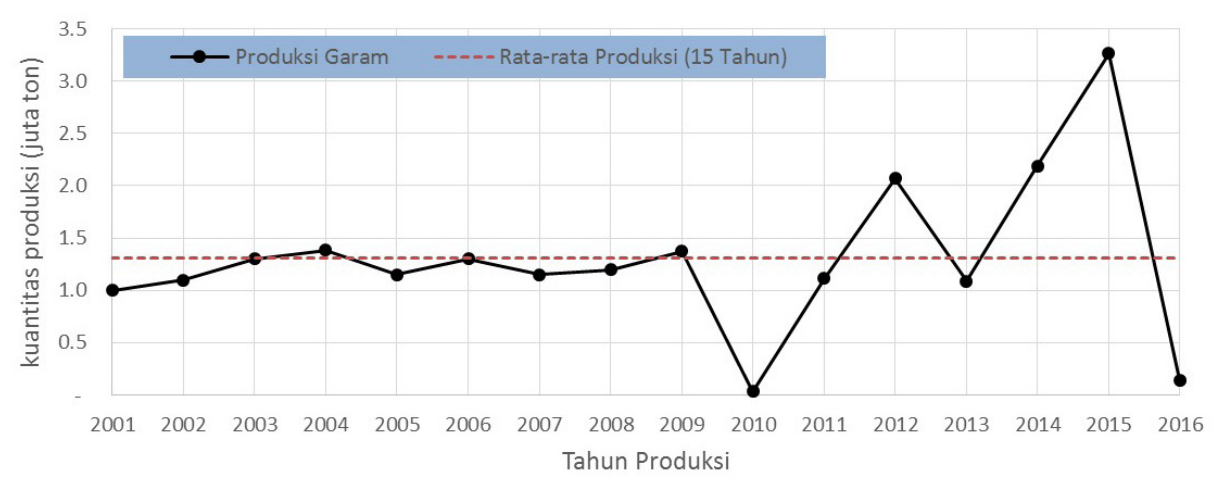

Gambar 2. Data Produksi Garam Nasional (2001-2016)

Figure 2. Data of National Salt Production (2001-2016)

biaya produksi yang tidak tertutupi oleh hasil panen yang disebabkan oleh terjadinya "gagal panen" garam di tingkat petambak. Pada skala yang lebih luas, informasi ini juga dapat dijadikan dasar bagi pengambil kebijakan untuk menjaga sufficiency stok garam dalam periode tertentu. Sehingga dapat diputuskan dengan cermat dan tepat seberapa besar kebutuhan garam nasional dapat dipenuhi oleh produksi dalam negeri dan impor.

\section{BAHAN DAN METODE}

Penelitian ini menggunakan data SOI tahun 1981-2016 yang diperoleh dari Biro Meteorologi Australia (BOM, 2017), data DMI tahun 1981 - 2017 yang diperoleh dari Badan Meteorologi Jepang (JAMSTEC, 2017), data statistik hasil produksi garam dari Kementerian Perindustian dan Kementian Kelautan dan Perikanan (Anonim, 2015), serta log book yang dibuat petambak garam dari Kaliori Rembang (1972-2016). Penelitian ini bersifat kualitatif dengan menggunakan jenis penelitian studi literatur, yang mengkomparasikan antara kejadian ENSO dan IOD dengan data curah hujan, serta hasil produksi garam tahunan.

\section{HASIL DAN PEMBAHASAN}

Secara sederhana dapat dipahami bahwa fluktuasi suhu permukaan laut di wilayah ekuator Samudera Pasifik yang menyebabkan terjadinya $\mathrm{El}$ Nino berasosiasi dengan kondisi kering atau curah hujan rendah dan sebaliknya La Nina membuat kondisi lebih basah atau curah hujan tinggi di sebagian besar wilayah Indonesia. Sementara fluktuasi suhu di wilayah ekuator Samudera Hindia menyebabkan terjadinya fase $I O D$ positif yang berasosiasi dengan rendahnya curah hujan dan $I O D$ negatif yang cenderung pada kondisi curah hujan tinggi di wilayah Indonesia dan sebagian Australia.

Tertampil pada Gambar 3, terlihat beberapa kejadian anomali fluktuasi suhu permukaan laut yang cukup ekstrim. Seperti yang terjadi pada akhir tahun 1997 yang menyebabkan rendahya curah hujan dan terjadinya musim kemarau panjang/kekeringan, sedangkan pada akhir tahun 2010 terjadi peningkatan curah hujan yang membuat kemarau lebih "basah" dari normalnya dan terjadi bencana banjir di beberapa daerah. Sektor yang paling rentan terhadap cuaca ekstrim adalah pertanian (Ruminta, 2016). Sehingga pada tahun 1997 gagal panen yang disebabkan oleh kekeringan melanda 3,9 juta hektar lahan pertanian dan merugikan Indonesia dengan total kerugian 466 juta dollar AS (Aksi Cepat Tanggap, 2017). Sedangkan pada tahun 2010 gagal panen disebabkan oleh banjir (Detik Finance, 2010).

Kondisi berbeda terjadi pada produksi garam, yaitu pada tahun 1997 terjadi panen besar-besaran. Namun sebaliknya pada tahun 2010, selain produksi garam dapat dikatakan gagal panen, menurut informasi kondisi tersebut diperparah dengan banyaknya garam yang sudah tersimpan dalam gudang kembali larut karena terendam banjir. Pada tahun 1997 wilayah Indonesia mengalami El Nino dan juga IOD positif sekaligus. Sedangkan pada 2010 wilayah Indonesia mengalami La Nina dan IOD negatif secara bersamaan.

Data curah hujan pada Gambar 3 merupakan data curah hujan bulanan yang diambil dari Stasiun Meteorologi Bandar Udara Ahmad Yani Semarang (BMKG, 2017), sebagai representasi dari kondisi curah hujan di Kabupaten Rembang yang merupakan salah satu sentra garam nasional. Hal tersebut dilakukan karena secara tidak disengaja penulis memperoleh data dari 


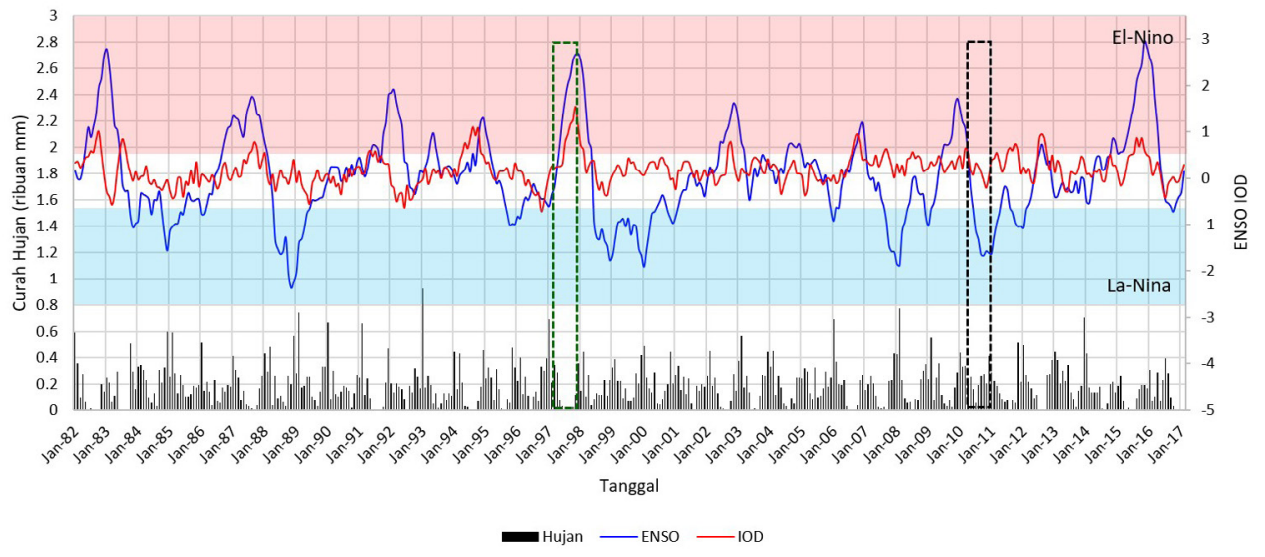

Gambar 3. Perbandingan Curah Hujan, ENSO dan IOD.

Figure 3. Rainfall Comparison, ENSO and IOD.

sebuah log book tentang kondisi musim panen garam di daerah Kaliori selama lebih dari 40 tahun (sejak Tahun 1972). Log book tersebut dibuat oleh Moch. Karlan, seorang pemilik tambak di Kecamatan Kaliori Kabupaten Rembang. Di dalam log book tersebut terdapat informasi intensitas hujan, naik turunnya harga garam, harga bbm, kejadian banjir atau kemarau panjang lengkap dengan detil tanggal kejadiannya.
Di dalamnya juga berisi ringkasan tahunan lamanya musim garam dan banyaknya hujan selama musim kemarau (Tabel 2).

Data lamanya musim garam dari log book tersebut diverifikasi menggunakan data curah hujan yang telah dibuat dalam skala tahunan dari stasiun metorologi Bandar Udara Ahmad Yani Semarang (Gambar 4). Dari

Tabel 2. Logbook Pencatatan Lamanya Musim Garam dan Hari Hujan

Table 2. Logbook of Recording Duration of Salt and Rainy Season

\begin{tabular}{llllll}
\hline Tahun & $\begin{array}{l}\text { lamanya } \\
\text { musim } \\
\text { garam } \\
\text { (hari) }\end{array}$ & $\begin{array}{l}\text { banyaknya } \\
\text { hujan }\end{array}$ & $\begin{array}{l}\text { Tahun } \\
\text { (kali) }\end{array}$ & $\begin{array}{l}\text { lamanya } \\
\text { musim } \\
\text { garam } \\
\text { (hari) }\end{array}$ & $\begin{array}{l}\text { banyaknya } \\
\text { hujan }\end{array}$ \\
\hline 1972 & 162 & 5 & 1995 & 99 & (kali) \\
1973 & 84 & 26 & 1996 & 148 & 11 \\
1974 & 110 & 21 & 1997 & 173 & 26 \\
1975 & 115 & 17 & 1998 & 52 & 7 \\
1976 & 163 & 17 & 1999 & 125 & 11 \\
1977 & 130 & 7 & 2000 & 100 & 14 \\
1978 & 71 & 15 & 2001 & 97 & 11 \\
1979 & 78 & 12 & 2002 & 158 & 9 \\
1980 & 125 & 7 & 2003 & 133 & 11 \\
1981 & 80 & 5 & 2004 & 121 & 12 \\
1982 & 179 & 6 & 2005 & 93 & 10 \\
1983 & 94 & 4 & 2006 & 223 & 20 \\
1984 & 132 & 10 & 2007 & 145 & 14 \\
1985 & 136 & 16 & 2008 & 113 & 12 \\
1986 & 162 & 22 & 2009 & 188 & 18 \\
1987 & 160 & 15 & 2010 & 20 & 17 \\
1988 & 134 & 18 & 2011 & 127 & 7 \\
1989 & 101 & 8 & 2012 & 167 & 11 \\
1990 & 162 & 17 & 2013 & 82 & 18 \\
1991 & 84 & 4 & 2014 & 140 & 14 \\
1992 & 100 & 16 & 2015 & 175 & 7 \\
1993 & 166 & 23 & 2016 & 40 & 5 \\
1994 & 136 & 7 & & & \\
\hline & & 52 & & & 11 \\
\hline
\end{tabular}




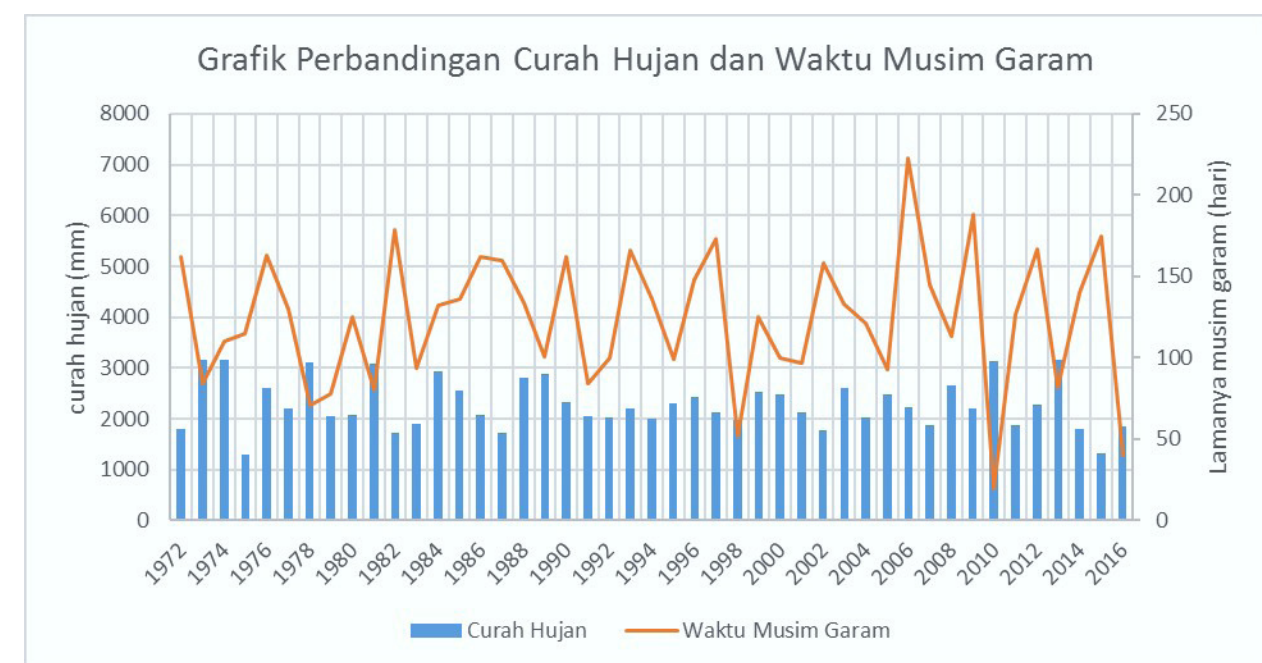

Gambar 4. Perbandingan Curah Hujan dan Waktu Musim Garam dalam 4 Dekade terakhir.

Figure 4. Comparison of Rainfall and Time of Salt Season in the last 4 Decades.

gambar tersebut terlihat bahwa data lamanya musim garam yang dicatat dalam log book relevan dengan data curah hujan tahunan dari stasiun meteorologi. Pada saat musim garam berlangsung lama maka curah hujan tahunan cenderung rendah seperti yang terjadi pada tahun 1997, 2012 dan 2015. Sebaliknya pada saat musim garam berlangsung pendek curah hujan tahunan cenderung tinggi, seperti yang terjadi pada tahun 1998, 2010 dan 2016.

Hubungan antara kombinasi kejadian ENSO dan $I O D$ dengan produksi garam, semakin terlihat dengan mencermatiGambar 5 dan Tabel 3. Meskipun data dalam log book tersebut tidak sacara eksplisit menampilkan data kuantitas produksi, namun berdasarkan informasi dari pembuat log book bahwa waktu kemarau dan lama musim garam mempengaruhi jumlah produksi garam. Semakin lama musim garam semakin banyak pula kuantitas produksi garam, dan sebaliknya. Pada keadaan gagal panen dapat dipastikan terjadi pada saat fase $I O D$ negatif bersamaan dengan La Nina lemah dan sedang. Pada saat tersebut lama musim garam hanya kurang dari 2,5 bulan, seperti yang terjadi pada tahun 1998, 2010 dan 2016. Sedangkan pada panen garam berlimpah umumnya lama musim garam berlangsung lebih dari 5,5 bulan. Hal tersebut terjadi pada saat fase $I O D$ positif bersamaan dengan El Nino lemah hingga kuat, sebagaimana yang terjadi pada tahun 1972, 1982, 1997, 2006 dan 2015. Hanya ada satu kejadian pada tahun 2009 musim garam berlangsung lama pada kondisi fase $I O D$ netral yang bersamaan dengan El Nino sedang. Panen garam normal dengan lama musim 4 - 5,5 bulan paling banyak terjadi pada fase $I O D$ netral bersamaan dengan ENSO normal dan El Nino sedang.

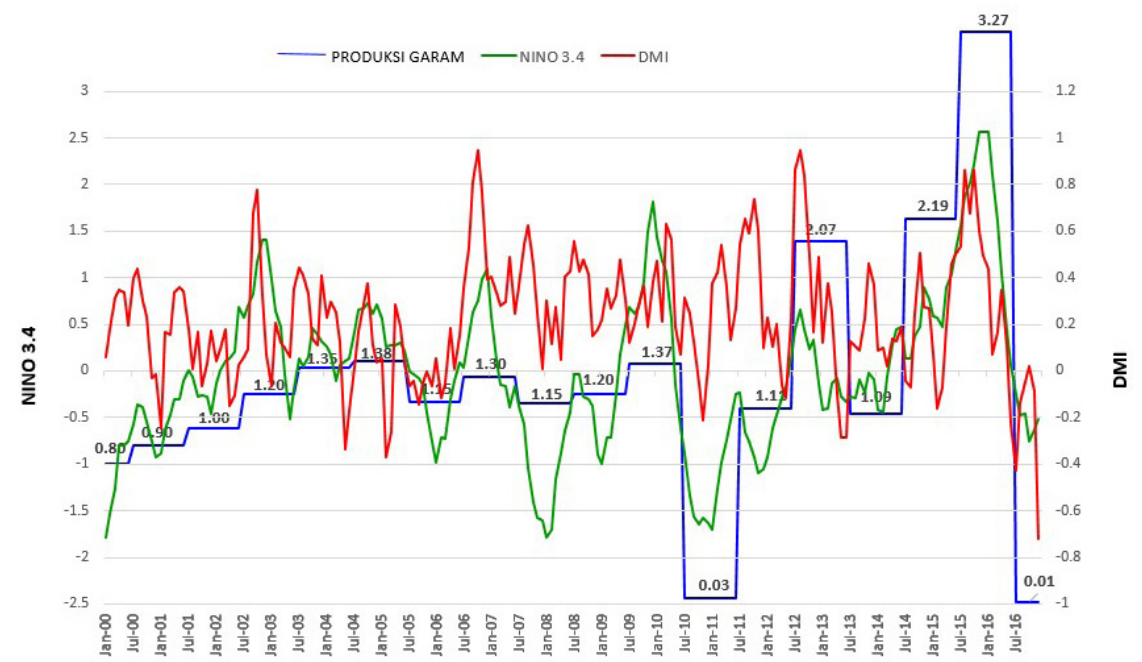

Gambar 5. Perbandingan ENSO, IOD, dan Hasil Produksi Garam.

Figure 5. Comparison of ENSO, Iod, and Salt Production Results. 
Tabel 3. Tabulasi hubungan kejadian ENSO dan IOD dengan lama musim garam

Table 3. Tabulate the relationship between ENSO and IOD events with salt season duration

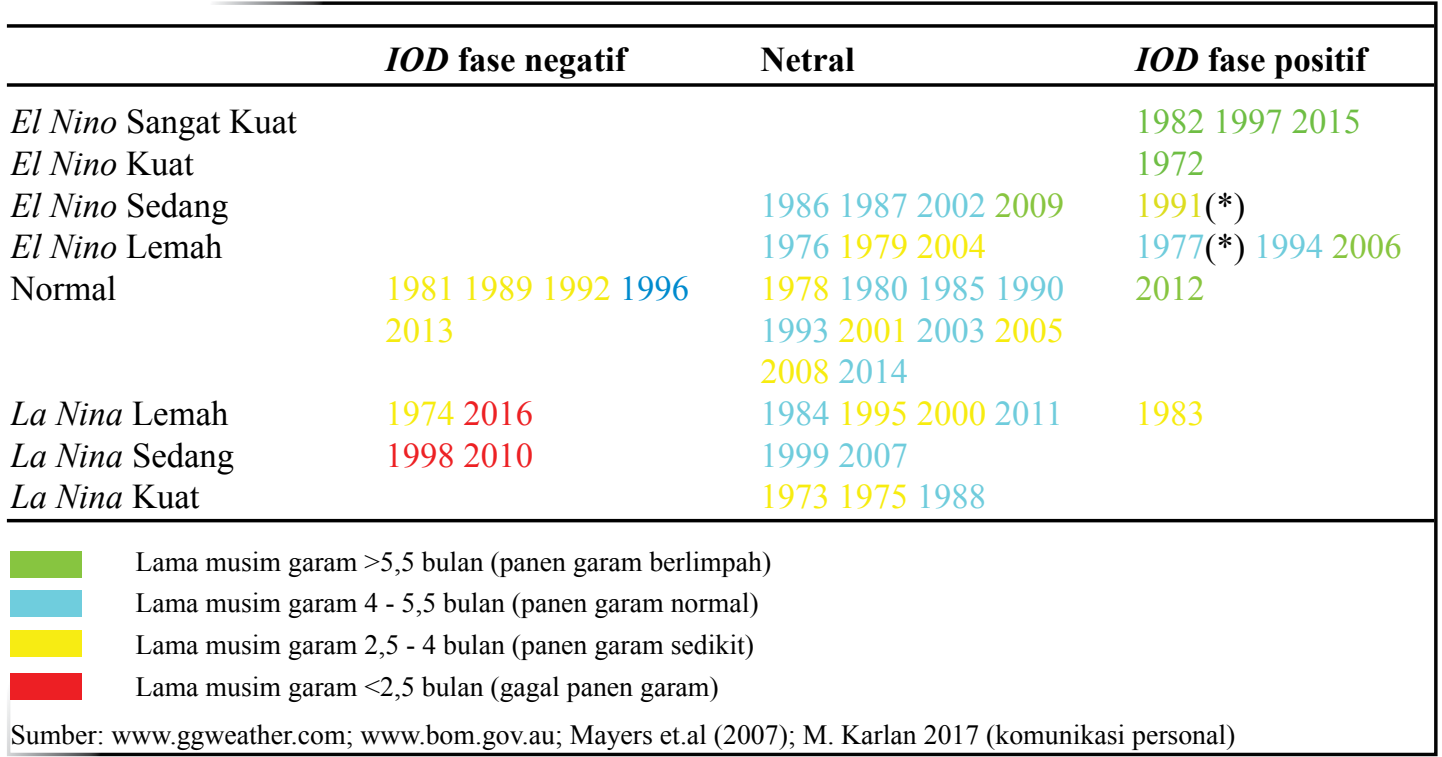

Namun demikian panen garam sedikit dengan lama musim 2,5 - 4 bulan juga cukup sering terjadi pada kondisi tersebut.

Informasi yang menarik adalah hampir semua kejadian gagal panen garam seperti yang terjadi pada tahun 1998, 2010 dan 2016 selalu didahului dengan panen besar-besaran di tahun sebelumnya yaitu 1997, 2009 dan 2015 yang ditandai dengan lamanya musim garam yang lebih dari 5,5 bulan sehingga panen garam berlimpah. Seperti diketahui bahwa pada tahun 1997 dan 2015 terjadi El Nino sangat kuat dan IOD positif di wilayah Indonesia. Di tahun berikutnya yaitu 1998 dan 2016 terjadi penurunan ekstrim menjadi La Nina yang bersamaan dengan $I O D$ negatif. Namun demikian meskipun pada tahun 2009 terjadi El Nino sedang dan $I O D$ netral, di tahun berikutnya dapat juga terjadi La Nina yang disertai dengan $I O D$ negatif seperti yang terjadai pada tahun 1998 dan 2016. Sehingga di masa mendatang perlu diwaspadai jika terjadi $E l$ Nino sangat kuat yang bersamaan dengan $I O D$ positif sehingga menyebabkan musim kemarau panjang atau musim garam lebih lama hingga lebih dari 5,5 bulan maka pada tahun berikutnya perlu diwaspadai adanya potensi gagal panen garam yang disebabkan oleh perubahan ekstrim menjadi La Nina bersamaan dengan $I O D$ negatif yang membuat kondisi musim kemarau cenderung "basah".

Dari beberapa tahun kejadian cuaca ekstrim yang berhubungan dengan jumlah produksi garam, jika data curah hujan dibuat dalam periode bulanan maka terlihat pola curah hujan spesifik pada tahun-tahun tersebut. Dari Gambar 6 terlihat bahwa curah hujan dengan pola terputus pada masa menjelang akhir tahun seperti yang terjadi pada tahun 2012 dan 2015, menunjukkan

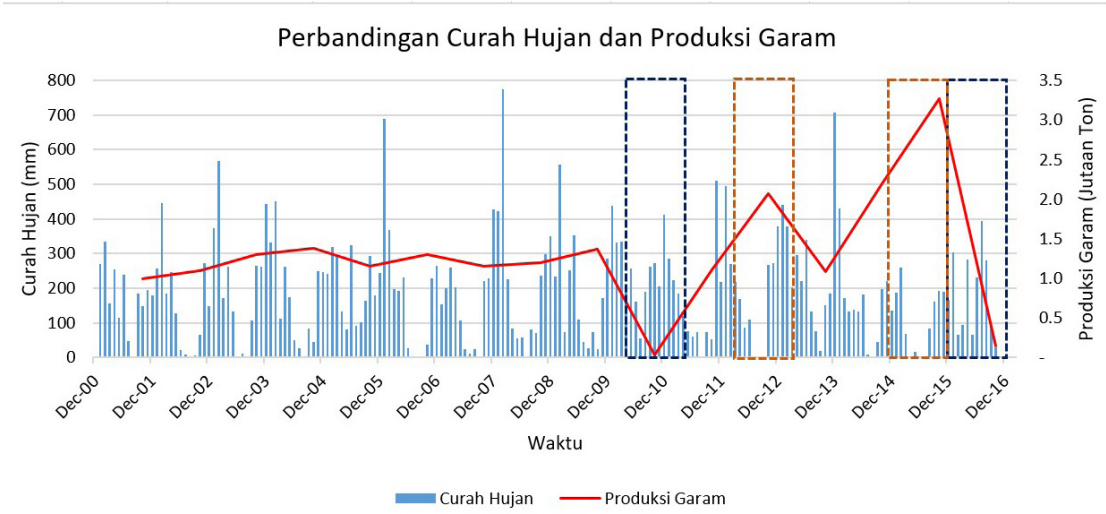

Gambar 6. Perbandingan Curah Huan dan Produksi Garam Nasional (2001-2016).

Figure 6. Comparison of Brain Huan and National Salt Production (2001-2016). 
peningkatan produksi garam. Sedangkan yang polanya menyambung pada menjelang akhir tahun seperti yang terjadi pada tahun 2010 dan 2016, produksinya mengalami penurunan drastis.

\section{KESIMPULAN DAN SARAN}

Pengamatan terhadap data dan informasi di atas menggambarkan bahwa tidak selamanya kejadian $L a$ Nina diikuti dengan penurunan jumlah produksi garam. Kondisi kritis dapat menghambat produksi secara signifikan hanya terjadi ketika perubahan secara drastis dari El Nino sangat kuat di tahun sebelumnya menjadi La Nina, serta bersamaan dengan kejadian IOD fase negatif, seperti yang terjadi pada tahun 1998, 2010 dan 2016. Sebaliknya, kejadian El Nino kuat hingga sangat kuat yang bersamaan dengan $I O D$ fase positif memperpanjang masa produksi dan meningkatkan kuantitas panen garam seperti pada tahun 1972, 1982, 1997, 2006, dan 2015.

Dengan mengetahui pola kuantitas produksi yang dipengaruhi oleh iklim, diharapkan dapat menjadi dasar bagi pengambil kebijakan untuk menjaga ketersediaan stok garam dalam rangka menyeimbangkan neraca komoditas garam sehingga harga tidak terlalu fluktuatif dan merugikan petambak garam maupun konsumen garam. Dan kejadian terpuruknnya produksi garam rakyat seperti yang telah terjadi setalah 1998 tidak terulang kembali.

\section{UCAPAN TERIMA KASIH}

Ucapan terima kasih disampaikan kepada Kepala Pusat Riset Kelautan. Terima kasih kepada Ketua Kelompok Penelitian Sumberdaya Air Laut dan Garam. Terima kasih kepada Bapak Moch. Karlan atas ijinnya menggunakan data dari logbooknya sehingga dapat dipergunakan dalam penyusunan artikel ini. Terima kasih kepada Dewan Redaksi, dan Mitra Bestari, dan kepada pihak-pihak yang tidak disebutkan dalam persantunan ini yang telah membantu dalam penyusunan artikel ini.

\section{DAFTAR PUSTAKA}

Aligori, A. (2013). Efficiency of Community-based Salt Production in Indramayu District. Thesis. IPB

Anonim. (2015). Materi Koordinasi Pembahasan Kebutuhan Garam Industri Aneka Pangan Dan Tim Swasembada Garam Nasional, tanggal 9 April 2015, di Kantor Kementerian Koordinator Bidang Perekonomian - RI
Aksi Cepat Tanggap. Dampak El-Nino th. 97-98: Catatan Bencana Kekeringan Terparah di Indonesia diakses 12 Juni 2017 dari http://blog.act.id/dampak-el-ninoth-97-98-catatan-bencana-kekeringan-terparah-diindonesia:

Apriyana, Y., \& Kailaku, T. E. (2015). Variabilitas iklim dan dinamika waktu tanam padi di wilayah pola hujan monsunal dan equatorial. Pros Sem Nas Masy Biodiv Indon, 1(2), 366-372. https://doi.org/10.13057/ psnmbi/.

Badan Meteorologi, Klimatologi dan Geofisika

Data Online; Pusat Data BMKG

Diakses pada 20 Juli 2017 dari http://dataonline. bmkg.go.id/ketersediaan_data

Bereau of Meteorology.

Southern Oscillation Index (SOI) since 1876

Diakses pada 20 Juni 2017 dari http://www.bom.gov. $\mathrm{au} / \mathrm{climate} /$ current/soihtm1.shtml

Indian Ocean influences on Australian climate

Diakses pada 21 Juli 2017 dari http://www.bom.gov. au/climate/iod/

Detik Finance. 100 Ribu Hektar Sawah Alami Gagal Panen di 2010 diakses 12 Juni 2017 dari http://finance.detik. com/berita-ekonomi-bisnis/d-1535482/100-ribuhektar-sawah-alami-gagal-panen-di-2010.

Endo, S., \& Tozuka, T. (2016). Two flavors of the Indian Ocean Dipole. Climate Dynamics, 46(11-12), 33713385. https://doi.org/10.1007/s00382-015-2773-0

Fadholi, A. (2013). Studi Dampak El Nino dan Indian Ocean Dipole (IOD). Jurnal Ilmu Lingkungan, Vol 11(No 1), 43-50. https://doi.org/http://dx.doi.org/10.14710/ jil.11.1.43-50.

Golden Gate Weather Services. Diakses pada 23 Juli 2017 dari http://ggweather.com/ENSO.

Hermawan, E. (2013). Estimasi Datangnya Kemarau Pajang 2012/2013 Berbasis Hasil Analisis Kombinasi Data Espi Dan Dmi, 12, 1-8. Retrieved from http:// puslitbang.bmkg.go.id/jmg/index.php/jmg/article/ view/79/73

Ina, J., Ruminta, Bayong Tjasyono H., Atika, L., \& Harijono, S. B. (2008). Pengaruh El Niño, La Niña dan Indian Ocean Dipole terhadap Curah Hujan Pentad di Wilayah Indonesia. Jurnal Bionatura, 10(2), 168177. https://doi.org/10.1038/43854.

Japan Agency for Marine-Earth Science and Technology. Diakses pada 17 juli 2017 dari http://www.jamstec. go.jp/frcgc/research/d1/IOD/DATA/IOD.monthly.txt

Kurniawan., Tikkyrino., \& Azizi, A. (2012). Climate change impact on salt ponds farmers in Sampang and Sumenep districts. Jurnal Masyarakat Dan Budaya, 14(3), 499-518.

Lan, M. (2012). Analysis of 2012 Indian Ocean Dipole Behavior.

Lee, H. (2015). General Rainfall Patterns in Indonesia and the Potential Impacts of Local Seas on Rainfall Intensity. Water, 7(4), 1751-1769. https://doi. org/10.3390/w7041751. 
Meyers, G., McIntosh, P., Pigot, L., \& Pook, M. (2007). The Years of El Niño, La Niña, and Interactions with the Tropical Indian Ocean. Journal of Climate, 20(13), 2872-2880. https://doi.org/10.1175/JCLI4152.1

Nur'utami, M. N., \& Hidayat, R. (2016). Influences of IOD and ENSO to Indonesian Rainfall Variability: Role of Atmosphere-ocean Interaction in the Indo-pacific Sector. Procedia Environmental Sciences, 33, 196203. https://doi.org/10.1016/j.proenv.2016.03.070

Ruminta. (2009). Pengaruh IODM dan ENSO Terhadap Awal dan Masa Tanam di Indonesia. In Seminar dan Simposium Meteorologi Pertanian VII (pp. 1-13).

Ruminta. (2016). Analisis penurunan produksi tanaman padi akibat perubahan iklim di Kabupaten Bandung Jawa Barat. Jurnal Kultivasi; 15(1), 37-45.

Saji, N. H., Vinayachandran, P. N., \& Yamagata, T. (1999). $A$ dipole in the tropical Indian Ocean. Nature, 401(September), 360-363.

T. Minzathu. (2017). Pengaruh ENSO Dan IOD Pada Tiga Pola Curah Hujan di Indonesia. Skripsi. Universitas Hasanudin. 57 halaman.

Utami, A. W., Jamhari, \& Hardyastuti, S. (2011). El Nino, La Nina, Dan Penawaran Pangan Di Jawa Indonesia. Jurnal Ekonomi Pembangunan, 12(2), 257-271.

Wahyono, A., Imron, M., Nadzir, I., \& Haryani, N. S. (2012). Vulnerability of Salt Fishers due to Rainy Season Changes in Randutatah Village, Probolinggo District (in Bahasa). Jurnal Masyarakat Dan Budaya, 14(3), 519-540. 